ADDIN, Volume 10, Number 2, August 2016

\title{
FEARS OF AN OPEN MARKET: \\ CITIZENS' VOICES OF THE ASEAN \\ ECONOMIC COMMUNITY (AEC)
}

\author{
Al Makin \\ Sunan Kalijaga State Islamic University Yogyakarta, Indonesia \\ almakin3@gmail.com
}

\begin{abstract}
This article presents the way in which Indonesian citizens responded to the idea of the open market in the South East Asian country established by the AEC. The article chooses some opinions published by the Indonesian media: Kompas, Dakwatuna, Koran Muria, Koran Yogya, Islam Pos, Hisbut Tahrir website, and Jawa Pos from 2014 to 2016 which show fears of and resistance against the free market. In the arguments they exbibit the fears which are motivated by the citizens' sentiments of nationalism and religion. The article also finds that the AEC is not well understood by the citizens of Indonesia, perhaps due to the lack of socialization by the government. Indeed, the AEC documents do not show any aspects outside economy as the main enterprise of the community, such as religion and nationalism which indeed motivated the fears of the Indonesian citizens. This led to difficulty by Indonesians to accept the idea of the free market who are mostly religious and hold nationalism in high regard. This paper also presents the detailed reasons and the arguments of the fears of the free market in the South East Asia.
\end{abstract}

Keywords: Open Market, ASEAN Economic Community, Religion. 


\section{Abstrak}

Artikel ini menjelaskan tentang bagaimana warga Indonesia menanggapi ide pasar bebas di negara Asia Tenggara yang digagas oleh masyarakat ekonomi ASE AN (MEA). Artikel ini memilib beberapa pendapat yang diterbitkan oleh media masa di Indonesia seperti: Kompas, Dakwatuna, Koran Muria, Koran Yogya, Islam Pos, situs Hizbut Tabrir, dan Jawa Pos sejak tabun 2014-2016. Dimana banyak pendapat yang dimuat di media tersebut menunjukkan kekhawatiran dan perlawanan terhadap pasar bebas. Argumen mereka menunjukkan akan ketakutan yang termotivasi oleh sentimen nasionalisme dan agama. Artikel ini menemukan bahwa masyarakat ekonomi ASEAN (MEA) tidak dipahami dengan baik oleh warga Indonesia, mungkin karena kurangnya sosialisasi oleh pemerintah. Memang, bukti gagasan masyarakat ekonomi ASE AN (MEA) tidak menunjukkan aspek di luar ekonomi seperti agama dan nasionalisme yang merupakan ketakutan warga negara Indonesia sebagai isu utama. Hal ini yang menyebabkan kesulitan orang Indonesia untuk menerima ide pasar bebas. Artikel ini juga menyajikan tentang alasan dan argument rinci dari kekhawatiran pasar bebas di Asia Tenggara.

Kata Kunci: Pasar Bebas, Masyarakat Ekonomi Asean, Agama.

\section{A. Introduction}

This writing is about some voices of Indonesian citizens about the AEC (ASEAN Economic Community/ MEA in bahasa Indonesia or Masyarakat Ekonomi Asean), which, however, do not represent professional or expert opinions from particular field of study. It is written based on some responses of Indonesian media to the AEC which aims at establishing an open single free market in the region in response to the competitive globalized world market. This article is not based on economic understanding or pragmatic political point of view. Neither does this article offer a criticism to or forecast of the AEC's future. This piece contains some voices of citizens in the way in which they understand their political leaders who envision the future of ASEAN (Association of South East Asian Nations) 
to form a single free market in which flows of goods and skilled labor can take place. These responses presented in this article describe that the AEC as an economic enterprise still needs to consider other issues outside it, such as cultural and religious aspects. This article presents a quick glance at the website of the AEC through limited documents available online and reading few responses from Indonesian media which however shows negative reactions to the AEC. Only too few, however, sees that the AEC is an opportunity for the Indonesian society, but we Indonesian should be better prepared.

In the presentation, this writing will explain the basic principles of the AEC taken from the website, quoting some important statements of the definition, characteristics, and goals. The articles then presents some voices of Indonesians taken from the online Media, Kompas, Jawa Pos, Hisbut Tabrir, Koran Muria, and Dakwatuna. From the opinions written in these media we can see that these writers voice fears more than optimism with the AEC. Their fear based on three reasons: the sense of nationalism by which they see the danger or at least threat of the AEC to Indonesian integrity and unity, such as the possible decreasing role of bahasa Indonesia; the unpreparedness of Indonesian human resources compared to other nations in the South East Asian; and religious reason by which they argue that the free market will bring a negative impact upon morality of Indonesian Muslims. Thus the real challenge in promoting the AEC can be said as religion and nationalism, which are clearly said by the writers in the media below. The negative reactions from Indonesian citizens can also be caused by the lack of knowledge of the citizens about the AEC. The government then needs a better way of socialization and proliferation of the idea of the AEC. It seems that the AEC should also consider other aspects outside economy in order to win the minds and hearts of citizens of the nations in the region. Only promoting economy is not sufficient to unite 
the nations in the region. However, before discussing further the issue and reactions to the AEC by Indonesian citizens, let us briefly discuss the nature of the AEC based on the documents available in the website.

\section{B. Discussion}

\section{The ASEAN Economic Community (AEC)}

The idea of unity and more economic cooperation of Asian countries which should open to each other with free trade inevitably recalls the way in which the European countries formed the European Union started from the end of 1950s. The aftermath of the devastation of Europe due to wars motivated mostly by narrow nationalism and chauvinism led to the awareness that unity and open market can bring prosperity. Openness among countries in Europe should heal the wound of division and conflicts in politics. Free movement among citizens brings solidarity in economy. This idea in economy was started by the six countries: Belgium, France, Italy, Luxembourg, the Netherlands and West Germany which signed the treaty of Rome in 1957 which gave birth to the European Economy Community (EEC). After this initiative in economic cooperation, of course the European Union still witnessed a long history of the development of unity among the country members, along with its treaties, membership, structure, and council. However, the pivotal transformation of the EU into reality is the Treaty of Maastricht in 2009 pioneered by the governments of French and Germany. But the latest development of the United Kingdom (UK) which held a referendum to exit from the Union (Brexit) in 2016 brings us to another point at which we should contemplate further and deeper about the union that the close cooperation among countries with regard to identity in a more globalized world. Unity does not only bring cooperation and solidarity but it can also threat "identity" of each nation. In the union many envision plurality and diversity, by which 
many expect that the merger of various European cultures with different ethnicities, cultures, faiths, and most importantly ideas will lead to a different peaceful and prosperous Europe. Indeed, the union does. However, the recent phenomena of immigration from other continents due to various conflicts to the European countries lead to yet resistance of the citizens. Foreign and alien elements intruding into a nation's identity can have negative side effects, such as the example of the relation of Islam and Europe which further heighten the discussion of plurality and globalization. ${ }^{1}$ All in all, this openness, unity, free movement, free trade, and solidarity in justice, equality in humanity in Europe inspired the Asian countries to establish a similar open community at least in economy.

Once again, the Asian Economic Community is inspired by the European Union and at the same time was formed in response to the emerging global competitive market. To put simply, the AEC is an economic enterprise with economic goal and means. To simply take the words from the website:

The establishment of the ASEAN Economic Community (AEC) in 2015 is a major milestone in the regional economic integration agenda in ASEAN, offering opportunities in the form of a huge market of US\$2.6 trillion and over 622 million people. In 2014, AEC was collectively the third largest economy in Asia and the seventh largest in the world ${ }^{2}$.

The AEC website releases various booklets and documents explaining its nature, history, philosophy, goal, and milestones to be achieved. One of the factsheets released in the website says that:

${ }^{1} \mathrm{Al}$ Makin, "Benedict XVI and Islam: Indonesian Public Reactions to the Regensburg Address," Islam and Christian-Muslim Relations 20, No. 4 (2009), p. 409-21; Al Makin, "Revisiting Indonesian Public Reactions against Danish Cartoons Depicting Prophet Muhammad," Indonesian Journal of Islam and Muslim Societies 5, No. 2 (2015), p. 195-229.

2 "ASEAN Economic Community, One Vision One Identity One Community," ASEAN | ONE VISION ONE IDENTITY ONE COMMUNITY, (Accessed August 4, 2016), http://asean.org/asean-economic-community/. 
The first ASEAN Economic Community (AEC) Blueprint, signed in November 2007, has served as a comprehensive master plan to chart the region's journey towards the formal establishment of the AEC on 31 December 2015. Under this Blueprint, the AEC is built on four interrelated and mutuallyreinforcing characteristics: (a) a single market and production base, (b) a highly competitive economic region, (c) a region of equitable economic development, and (d) a region fully integrated into the global economy ${ }^{3}$

The characteristics of the AEC is further explained in the same document that the AEC will create "a single market" with "free flow of goods, services, investment, skilled labor and freer flow of capital." This will catapult, and boost, a business friendly environment in the South East Asian countries particularly in the fields of "agriculture and financial services, and in competition policy, intellectual property rights, and consumer protection." This will further push, and encourage, small and medium enterprises in the region to participate in the global economy. ${ }^{4}$

The AEC also publishes a book which argues that the ASEAN with its members of Brunei Darussalam, Cambodia, Indonesia, Lao PDR, Malaysia, Myanmar, the Philippines, Singapore, Thailand, and Viet Nam is the third largest population of the world with 622 million people after China and the USA in 2014. From 2007-2014 the GDP was $76 \% .^{5}$ This big size population and economic growth, this document goes further, is a vital capital to enter the increasingly globalized economy. The book also argues that cooperation and open market will benefit more to forming identity and collectivity of the South East Asian countries, as the symbol of the AEC is "one vision,

3 "Fact Sheet on Asean Economic Community" (Asean Economic Community, December 2015), http://asean.org/asean-economic-community/.

${ }^{4}$ Ibid.

${ }^{5}$ A Blueprint for Growth ASEAN Economic Community 2015: Progress and Key Acbievements ASEAN (Jakarta: The ASEAN Secretariat, 2015), p. 2, http://asean.org/aseaneconomic- community/. 
one identity and one community" (The words appear in many booklets and websites). In the end, the book argues that "The ASEAN Leaders envisioned a 'post-2015 ASEAN' that will be politically cohesive, economically integrated and socially responsible". "All economic cooperation is further explained in details in the book, such as how to achieve the goals and targets through regulations and governmental policies. However, general readers will be disappointed for failing to find other urgent issues in the South East Asian society: politics, conflicts, poverty, inequality, discrimination, human rights, etc. Economy is important in life, but other issues will contribute to economic development. The AEC remains silent in relating economy to other factors.

The AEC is all about economy, digital technology, market, agriculture, intellectual property right, flow skilled labor, etc, but too little attention is given to other aspects of the South East Asian countries: politics, human right, culture, religion, ethnicity, without which collective identity cannot be achieved. It is worth noting that the South East Asian countries are plural in terms of these criteria, but the AEC documents do not address these issues. Progress in economy without foundation of culture, education, and political education seems elusive. In another document which goes into details of the policy and the way the open market is promoted to compete in the global economy is explained, but too little to pay attention to tourism:

The AEC 2025 vision for tourism is for ASEAN to be a quality tourism destination offering a unique, diverse ASEAN experience, and committed to responsible, sustainable and inclusive tourism development, so as to contribute significantly to the socio-economic well-being of ASEAN peoples. ${ }^{7}$

${ }^{6}$ Ibid., p. 30.

7 ASEAN Economic Community Blueprint 2025 (Jakarta: The ASEAN Secretariat, 2015), p. 26, http://asean.org/asean-economic-community/. 
The detailed argument released in the booklet and papers of the ASEAN website is, however, technical. To what extent this can be understood by the citizens of the South East Asian countries is another issue which remains unanswered. The top leaders in the countries creating this policy and political institution can understand the urgent of the unity of ASEAN community which envisions a better future by merging different countries, but how the common people and local governments at the local levels have such an understanding of the AEC is a different issue.

This paper will not pinpoint all weaknesses and reject the possibility of merging South East Asian countries into a single community. This paper is not the right place to do so, as the perspective in this paper is limited to the citizens of Indonesia with regard to religious and nationalist aspects. Indeed, the vision of the AEC is progressive and its existence promises a better future of the ASEAN countries in the global market. Nor does this paper pinpoint the bad idea of the initiative and debunk the urgent unity of the ASEAN with the common identity for a better society. However, this paper rather exposes the way in which Indonesian audience understood and reacted to the AEC between 2014-2016. This paper selects few newspapers' opinions and comment on these responses particularly in the sector of socialization and proliferation of the idea, as to why negative reaction emerged.

\section{Fears of an Open Market}

Indonesia is the largest county in the South East Asia, with Muslim majority dominating the world map. Indonesia, like the rest of ASEAN countries, is diverse in history, religion, ethnicity, culture, and tradition. This aspect which does not appear in the most documents of the AEC cries a further attention. Indonesia should take a lead in establishing the AEC due to the previous role in the ASEAN organization. With the 
large population and diverse culture Indonesia can contribute to Asian development in economy and culture and perhaps to the world. However, this capital should be further cultivated. However, lately the diverse cultural Islamic religiosity has been faced with conservatism and radicalization, which hit the country since the reformation period, marked with the fall of Soeharto from power. ${ }^{8}$ The period of reformation is the era of democratization, where multi-political party system is adopted. During the tight political control of the New Order only three main political parties compete in many general elections. The free public space, however, bring another consequence. That is, conservatism and radicalization, which was suppressed by the New Order, resurfaced in the public domain and seized the opportunity to voice Islamist ideology. In the reactions to AEC which will be presented below the conservative Islamist tone can also be seen.

As the agreement among the South East Asian countries that by the end of 2015 the AEC would be started, by the beginning of 2014 and 2016, some newspapers made headlines about the AEC and published opinions about the free market. From this, we can see that the AEC is not totally welcome, nor well understood by the citizens of Indonesia. The AEC seems to be an alien idea threatening the identity of Indonesians in terms of nationalism and religious sentiments. Some writers recalled the history of the unity of the country which was achieved by a long struggle; and to unite the islands separated by sea remains an ongoing process. The AEC can be a possible danger to the unity of the country. ${ }^{9}$

\footnotetext{
${ }^{8}$ Robert W Hefner, "Religious Resurgence in Contemporary Asia: Southeast Asian Perspectives on Capitalism, the State and the New Piety," The Journal of Asian Studies: Review of Eastern and Southern Asia and the Adjacent Pacific Islands 69, No. 4 (2010), p. 1031-47; Al Makin, Challenging Islamic Orthodoxy, Accounts of Lia Eden and Other Prophets in Indonesia (Dordrecht, Holland; Cinnaminson [N.J.], U.S.A.: Springer, 2016).

${ }^{9}$ For the issue of nationalism, identity, and religion, see, for instance, Benedict R. O'G. Anderson, Imagined Communities: Reflections on the Origin and Spread of Nationalism (London; New York: Verso, 1991); Benedict R. O’G. Anderson, Language and Power: Exploring Political
} 
The opinions presented below feature fears of an open market advocated by the AEC. The fears have foundation in nationalism and religion. Only few statements show optimism that the AEC can become an opportunity for Indonesians. The following discussion will present the writings of Dwi Erianto in Kompas, Nabilah Syifauz Zahra in Dakwatuna, Khoirika Makhmudah in Koran Muria, Iswadi Nawai in Koran Yogya, Estyningtias in Islam Pos, Gunoto Saparie in Koran Muria, Dwi Condro Triono in Hisbut Tabrir website, and Badrut Tamam in Jawa Pos.

To begin with, let us read an opinion published by Kompas, the largest newspaper in Indonesia. Dwi Erianto ${ }^{10}$ writes that the free market in the AEC concept is like a sword with two edges for Indonesia. If the society and government are well prepared to compete with other Asian countries in the free market, the AEC can catapult Indonesia into the largest market and labors in the region. Goods and products from the country can dominate the region's market. However, Dwi Erianto argues, if the AEC's agreements are not responded to by good preparation by Indonesia, the country will become a mere market for the products coming from other neighboring countries. Indeed, the AEC is both opportunity and threat to Indonesians. The belief by Asean leaders in 1997 that the AEC will push the countries in the region to compete with the largest players in Asia, such as India and Asia can become a reality, but disaster can also fall. True, the AEC can create jobs and boost the economy. With the AEC agreements, skilled and professional labors such as scientists, doctors, engineer, architect, lawyer, can move from one country to another. This can create a dynamic and exchange of professionalism. Science, technology, and knowledge can

Cultures in Indonesia (Ithaca, N.Y.: Cornell University Press, 1990); Al Makin, "Are There any Indonesian Philosohers? Dealing with a Common Question and Possible Answers," Ulumuna 20, No. 1 (2016), p. 1-28.

${ }^{10}$ Dwi Erianto, "MEA, Antara Peluang Dan Ancaman,” Kompas, (December 1, 2015), http://print.kompas.com/baca/2015/12/01/MEA\%2c-Antara-Peluang-dan-Ancaman. 
easily be transferred among the countries. In fact, Indonesia is the largest in population with more than 250 million people. However, according to the survey by the Kompas in 2015, most Indonesians do not know, or have no awareness of, the AEC. The survey indicates that almost all levels of Indonesians from the low income to high income do not know the AEC. This shows the lack of proliferation and socialization of the AEC. According to the survey only one of twenty respondents knows the AEC, regardless whether their knowledge of the AEC is sufficient or not.

Fear also comes to Indonesians who felt inferior to neighboring countries, such as Singapore and Malaysia. To Singapore of course Indonesia is hard to compare in size, development, and progress, but to Malaysia Indonesians feel comfortable with the comparison as both have Muslim majority and share common history and culture. But Malaysia is perceived by Indonesians to have better preparation in education and professionalism. Universities in Malaysia are well prepared with researchers, whereas Indonesia still lags behind. However, Erianto shows optimism at the same time that Indonesians will increase the quality of products and professionalism in order to compete in the Asean market. Indonesian can learn lesson from other neighboring countries.

Nabilah Syifauz Zahra from the website of Dakwatuna ${ }^{11}$ voices her fears of the AEC. She highlights the free movements of labor in the South East Asian countries. With the AEC, citizens of the member countries can move to another without difficulty. The flow of products and professionals will give a different picture of the region. However, she shows fear that Indonesians, not well trained and educated as other developed

${ }^{11}$ Nabilah Syifauz Zahra, "Efek dan Dampak Pemberlakuan Masyarakat Ekonomi ASEAN (MEA)," Dakwatuna, (January 1, 2015), http://www.dakwatuna. com/2015/01/15/62615/efek-dan-dampak-pemberlakuan-masyarakat-ekonomi-aseanmea/\#ixzz4GJWQBpKY. 
countries, will supply only unskilled labors who cannot compete with more professional labors from other countries. She fears that Indonesia will be flooded by more skilled labors from other countries. Indonesia will have less benefit than negative side of the AEC will bring to the country.

Interesting light from Zahra is the role of women in the family when faced with the free market of the AEC. Zahra imagines that due to highly busy world market and demand of economy of the family, women should also work in the offices or factories. As a result, women will have less time to the family. Zahra fears the education of the family will deteriorate, due to the fact that children are faced with lack of attention from mothers. Zahra also fears adegradation of morality for children during the AEC implementation, which can also bring a negative side, such as bad influence of the abuse of drug, alcohol, and sex. Zahra also anticipates that sex commercialization, like other products and goods, will also come to the free market of the AEC.

Khoirika Makhmudah is a student of the State Islamic University Walisongo Semarang and NGO activist who has different view of the AEC. Makhmudah warns the preparedness of the Indonesians to the AEC. ${ }^{12}$ Makhmudah sees that Indonesians are not well prepared to face the AEC in terms of the quality of Indonesian labors and education. Given this, Indonesia cannot compete well with more developed neighbors in the region. To present her words:

The policy (of the AEC) is good and should be established. But, the policy can stir controversy and debate in society, particularly in Indonesia. With the AEC, whether our country can meet what expected by the South East Asian standard is a vital issue. With the current situation, many, however, cast

${ }^{12}$ Khoirika Makhmudah, "MEA Dan Semangat Nasionalisme," Koran Muria, (December 5, 2015), http://www.koranmuria.com/2015/12/05/24126/mea-dan-semangatnasionalisme.html. 
doubt that Indonesia is ready to face the free market in the region.

Makhmudah sheds light on the sense of patriotism of Indonesians which has lately faded away. ${ }^{13}$ In using local products, for example, Indonesians seem unaware of the benefit of consuming local products. They prefer imported products which show a better packaging, albeit they do not guarantee a better quality in content. She notes that Indonesians are easily deceived by packaging. She presents an example of oranges from China which look more beautiful in skin than local oranges. In fact, the taste and quality of local agriculture are not necessarily worse than those of China. But with a better look and cheaper in price, Indonesians are easily lured to consume foreign products.

Due to the flood of products in Indonesian market, the people can easily ignore the work of process due to the availability of the foreign products in the market. Makhmudah warns about this issue. Health issues also receives Makhmudah's attention in her writing. Apple from outside the country, for example, often contains dangerous bacteria due to a long storage and travel to Indonesia. Many foreign products are not well controlled in quality.

Iswadi Nawawi sheds light on the role of English as the main tool of communication in the AEC and the possible difficulty for Indonesians to participate in communication who prevalently speak bahasa Indonesia and have trouble with learning English. ${ }^{14}$ Nawawi realistically sees that English is the most common language in the world and now in the South East Asian countries. Thus, the use of this language is effective to connect the AEC society. In the website and elsewhere in the brochures and booklets, the AEC officially uses English. Nawawi

\footnotetext{
${ }^{13}$ Ibid.

${ }^{14}$ Iswadi Nawawi, "Nasib Bahasa Indonesia Dalam Telikungan MEA," Koran Yogya, (January 6, 2016), http://koranyogya.com/mea-dan-nasib-bahasa-indonesia/.
} 
is critical that no information available is in bahasa Indonesia, a fact which can become an obstacle for Indonesians, who have right to receive the correct information about the AEC and to communicate with the AEC leaders and other society.

The trouble in English, however, can have positive side in that this will encourage Indonesians to learn the language. At the same time he fears that bahasa Indonesia will someday loose its role when English is preferable and more dominant in the AEC.

Nawawi puts it:

In my perspective, the AEC will be filled with tough competition which will bring a social dynamism. Besides the wars of capital in economy and trading activities between Indonesia and the ten other members in the South East Asia, the competition will also happen in other aspects of life in society, such as in political, social, legal, and cultural aspects. One aspect which is easily predicted is the competition of language or the tool of people communicating in 2015. English will be used in communication and will dominate all businessmen in the region. English will prevail over bahasa Indonesia. Given this, one may wonder the future of bahasa Indonesia, which is the main tool of formal and informal communication for Indonesians.

Nawawi then recalls the way unity among islands in Indonesia has remained intact due to the role of bahasa Indonesia. He returns to the way old Majapahit prime Minister Gajah Mada united the archipelago with a great effort. He also appreciates the young leaders of Indonesia during revolution delivered "oaths" by putting bahasa Indonesia as the main factor uniting various ethnicities, faiths, and traditions. He fears that the use of English will become disintegrating factor threatening the unity of Indonesia as a nation.

Nawawi also cites the government regulation number 24 year 2009 on the use of the state's flag, language, symbol, and anthem. The first verse says "Indonesian language must be used in any MOU or agreements which involve state, 
governmental institution of the Republic of Indonesia, Indonesian private institution or CV belonging to Indonesian citizens." This contradicts the fact that English serves as the main language of the EAC. And chapter 33, verse 1 of the National Constitution also stresses that "Indonesian language must be used as the tool of communication officially in the government and private institution." For Nawawi, the use of English in the AEC documents and as a tool of communication indeed does break the laws and the Indonesian government regulation. However, the regulation and law do not give a clear sanction for the violation. Nawawi is also realistic that the current world has forgotten local language, such as Indonesia, whose vocabularies and structure have already been infiltrated by international languages.

Estinngtyas highlights that the free market in the South East Asian countries serves for the interest of global free competitive market but not the people of the region. The free market does protect the weak in each country members. The competition itself fears Estiningtyas, as it is cruel regardless of the classes in economy, knowledge, and technology. She puts it:

In the free market, all participants are given freedom in competition. There is no control whatsoever; whoever wants to join is welcome to enter the free market. Like in a boxing ring, all can enter the ring without regarding the class, whether a boxer belongs to heavyweight, lightweight, or only featherweight. All boxers are encouraged to fight against each other directly in the same ring. All can easily predict that those who are strong will win effortlessly.

Estyningtias ${ }^{15}$ sees that the quality of Indonesian human resource is not sufficient to openly enter the free market in the South East Asian countries. Astyningtias points that the human index of Indonesia is ranked number 124 among 128

${ }^{15}$ Estyningtias P, “Masyarakat Ekonomi ASEAN; Tantangan Atau Ancaman?, Islam Pos, (March 18, 2014), https://www.islampos.com/masyarakat-ekonomi-asean-tantanganatau-ancaman-102209/. 
countries in the world. This means that Indonesia will bring more unemployment if the free market is implemented by the country. Or else, Indonesian non-professional labors will flood other nations.

Estyningtias says that the poor Indonesian citizens will be faced with more poverty. The theory of labor wage in liberal economy leads to nowhere but to this result. According to the liberal market, the wage cannot either be increased or decreased. Unfortunately, the wage is not good. But the payment is low. Estyningtias explains that why the wage cannot be increased, because when the workers hold demonstration, the capital owners will show that there are many unemployment outside there in the world who are in line to get the jobs. If the workers want to keep the job, they have to accept the wage decided by the capital owners. The workers will be faced with pressure with unsatisfying condition and continue the job.

For Estyningtias, the AEC is part of imperialist scheme to weaken Muslims in the world. Indonesia is a home to the biggest number of Muslims. The Western country wants to strengthen their grip over the South East Asian countries in economy. For Estiningtyas AEC is threat not opportunity. The threat comes from Western imperialists who want to perpetuate their hegemony over the developing countries such as Indonesia. ${ }^{16}$

Estyningtias calls on Muslims to unite to oppose the AEC. But the AEC does not consists merely individual gathering; it is a system which is too strong. The AEC is also a strategy for a system to colonize Muslims in the South East Asian countries. She puts it:

The AEC is a strategy to achieve a system. To fight the system we do need another system, not merely gathering of individuals. Thus, we need a system where world economy

${ }^{16}$ For the issue of the relation between the East and the West in Indonesia and Islam, see Al Makin, Antara Barat dan Timur: Batasan, Dominasi, Relasi, dan Globalisas: Melampaui Jurang Masa Lalu untuk. Meniti Jembatan Penghubung (Jakarta: Serambi, 2015). 
can be re-ordered efficiently and effectively. And Islam as a caliphate system (daulab khilafah) with the economic system blessed by God is the answer to all of this.

Clearly, Estyningtias holds an Islamist theology in arguing that the AEC is a threat to destroy Islam and Muslims in Southeast Asia.

Gunoto Saparie adds another fact that that Indonesia from the sector of agriculture is not prepared to compete with other ASEAN countries. Commodities and goods are mostly imported, whereas Indonesia is weak in exporting the local products. He puts it:

But it has to be admitted that the agricultural sector so far to this day remains left behind and is burdened with a high volume of imported commodities in foods and horticulture which are increasing, such as rice, beans, corns, fruits, and garlic. For the country's consumption, the latest data shows our dependence on foreign product, like wheat, is $100 \%, 54 \%$ sugar, and $95 \%$ garlic. The needs for foods are increasing, but the government does not yet make an effort to decrease the imported dependence.

Saparie $^{17}$ sees some problems in agriculture facing Indonesia in the face of the AEC. Saparie mentions some areas of weaknesses which needs attention of Indonesian society and government. The first vital problem is related to the lands for agriculture, whose size is decreasing by years in quality, availability, and ownership of farmers. The second factor in agriculture which needs attention is infrastructure, particularly matters related to the limit of irrigation system and transportation of the products. Indonesian government needs to fix the problem so that the farmers can increase their productivity. Third is about the seeds whose cultivation needs a better institution with a better technology. Fourth is

${ }^{17}$ Gunoto Saparie, "Ketaksiapan Pertanian Hadapi MEA," Koran Muria, (June 20, 2015), http://www.koranmuria.com/2015/06/20/5591/ketaksiapan-pertanian-hadapi-mea. html. 
about regulation which protects the local farmers. The fifth is about human resource with the ability to master technology. Safarie sees that in fact the younger Indonesian generation has low interest in agriculture and lack of knowledge and skill in farming. And the sixth is the difficulty facing the Indonesian farmers to get financial aids.

For Saparie, worse still, the agricultural sector is faced with the current development of global warming and uncertain rainy season which do influence the way the farmers should cultivate the lands. Sapaie also writes that the market inside the country is also unstable, a situation which leaves the farmers with uncertainty with their products. On the other hand, the increase of population is certain. Saparie thus concludes that Indonesia is indeed not prepared to face the AEC.

Dwi Condro Triono adds another negative side of the AEC for Indonesian economy. The free market will bring commercialization of the basic needs of society. If Indonesia adopts the liberation of economy, the role of the state to regulate and control the people's economy will diminish. The people will have to pay all the needs, including basic service, such as health. ${ }^{18}$

Triono points out that all natural resources which are abundant in Indonesia in the liberal market will be owned by private companies. The state will no longer control the resource. Coal, fuel, and other mining products will be dominated by business consideration which will lead to the increase of price not affordable for the common people. Electricity, which is now basic need, will be handed over to the private companies. Alternative energy such as wind, solar, and wave are alternative sources. However, when private companies take over them, the price will increase and is not affordable for the people.

${ }^{18}$ Dwi Condro Triono, "MEA Dalam Pandangan Islam,” hiz̧but-tabrir.or.id, January 1, 2016), http://hizbut-tahrir.or.id/2016/01/01/mea-dalam-pandangan-islam/. 
Triono also fears of the free market with the AEC regulation in South East Asian countries. He, as an Islamist activist of the HTI, sees the free market does not accord with Islamic principles. But above all what he fears is the damage of the family institution in Indonesia. Triono imagines that when the economic and social competition is harsh, all men cannot be burdened any longer as the sole breadwinners, but the responsibility should also be borne by women. Women are expected to compete in the job market. Some of them will become domestic workers or low labors outside the country. This leads to ruin the foundation of family.

For Triono, Islam offers its own concept of economy which opposes liberalism and free market. Islam does not give freedom to all players, such as private companies in the systems of capitalism and liberalism. Triono believes that Islam sees that ownership of private sectors should be limited to individual ownership. Ownership of capital or resource which dominate society's needs is wrong. Natural resources and other important needs to the people should be owned by the state, which should guarantee the welfare of the people. If the governments, as suggested by the AEC, let the private companies control all people's needs, the government is no longer trusted and betrays the duty of the people.

Triono sees that the AEC is nothing but imperialism and colonialism designed by the strong to weaken the weak, a situation which opposes Islamic principle, which promotes justice and equality. Free market, competition without border, and liberation in economy is absolutely forbidden (baram). State, according to Islam, should regulate the relation between the states and between the people of the states. Triono argues that Islam does not let absolute freedom without border and control of private companies without regulation. Islam also obliges the state to guard the shariah and promote economy based on shariah law. 
Badrut Tamam also sees that Indonesia is not prepared to compete in the AEC market. ${ }^{19}$ The competition ability of the country is weak compared with other members of the AEC. According to some surveys, the price for export for local product is too high, compared to Brunei and Kambodia. However, the price for import products are the lowest. This describes that Indonesian businessmen have difficulty to sell their products abroad. But they can bring products from other countries easily. The price of the products abroad is not competitive due to price of taxation and regulation imposed by the government of Indonesia.

\section{Conclusion}

This article is written in the mid of 2016, almost one year after the implementation of the AEC in the South East Asian countries. The fears of the open market as discussed above started since 2014. Now the newspapers and other media do not report yet to what extent the damage has been brought by the AEC to Indonesia and Muslims in the country. Whether the damage of family foundation, the decreasing role of bahasa Indonesia in the society, the domination of foreign products over the local ones, or other negative impacts of the AEC visible in the country (as discussed by the abovementioned opinions of the newspapers) remains unclear. The fears of the citizens of Indonesia of the implementation of the AEC are based clearly on the sense of nationalism and religion. The resistance against the free market comes from the two factors. Religion and nationalism are indeed two important factors in Indonesia, perhaps also in other countries of the AEC, which, however, the AEC documents fail to address. This can be seen as weakness of the idea of forming a single identity of

${ }^{19}$ Badrut Tamam, "Rupiah dan Daya Saing Indonesia Di Pasar MEA," Jawa Pos, (July 4, 2015), http://www2.jawapos.com/baca/opinidetail/15381/rupiah-dan-daya-saingindonesia-di-pasar-mea. 
the South East Asian countries without mentioning, or at least anticipating, nationalism and religion. As these writers state and are discussed above, Indonesia is not prepared with the AEC in human resource and regulation, due to first of all the lack of knowledge of the citizens about what the AEC is. Secondly, the government does not make an effort to promote the idea of the AEC well to the people. This article finds that the AEC should be strengthened with cultural and religious aspects of the South East Asia. Particularly Indonesia as the largest country member is a religious society which deems the religious identity highly. If the vision of unity of the ASEAN countries does not involve both cultural and religious sides, not only does the idea will fail to attract the attention of the people, but it is also hard to be understood and proliferated among them.

The AEC seems not to include religious and cultural diversity as a critical factor which has formed the nations of the region, as clearly the idea still fails to reach the hearts and minds of Indonesians. In fact, Indonesia, and perhaps like the rest of other AEC countries, is plural in both aspects. ${ }^{20}$ It is also noteworthy that plurality and diversity still searches a better formulation from Indonesian scholars and better policy from the government of Indonesia. Indonesia has put the words Bhinneka Tunggal Ika (unity in diversity) as a symbol of the nation, but the reformulation and reinterpretation needs our attention. ${ }^{21}$ The AEC, however, does not seriously address the issue either. Unity without respecting diversity among the AEC members is difficult to materialize.

${ }^{20}$ Edith Franke, Einheit in der Vielfalt: Strukturen, Bedingungen und Alltag religiöser Pluralität in Indonesien (Wiesbaden: Harrassowitz, 2012).

${ }^{21} \mathrm{Al}$ Makin, Challenging Islamic Orthodoxy, Accounts of Lia Eden and Other Prophets in Indonesia; Al Makin, Keragaman dan Perbedaan, Budaya dan Agama dalam Lintas Sejarah Manusia (Yogyakarta: Suka Press, 2016). 


\section{REFERENCE}

A Blueprint for Growth ASEAN Economic Community 2015:Progress and Key Achievements ASEAN. Jakarta: The ASEAN Secretariat, 2015. http://asean.org/asean-economiccommunity/.

Anderson, Benedict R. O'G. Imagined Communities: Reflections on the Origin and Spread of Nationalism. London: New York: Verso, 1991.

. Language and Power: Exploring Political Cultures in Indonesia. Ithaca, N.Y.: Cornell University Press, 1990.

ASEAN Economic Community Blueprint 2025. Jakarta: The ASEAN Secretariat, 2015. http://asean.org/aseaneconomic-community/.

"ASEAN Economic Community One Vision One Identity One Community." ASEAN | ONE VISION ONE IDENTITY ONE COMMUNITY. Accessed August 4, 2016. http://asean.org/asean-economic-community/.

Erianto, Dwi. "MEA, Antara Peluang Dan Ancaman." Kompas, December 1, 2015. http://print.kompas.com/ baca/2015/12/01/MEA\%2c-Antara-Peluang-danAncaman.

Estyningtias P., "Masyarakat Ekonomi ASEAN; Tantangan Atau Ancaman?" Islam Pos, March 18, 2014. https://www. islampos.com/masyarakat-ekonomi-asean-tantanganatau-ancaman-102209/.

"Fact Sheet on ASEAN Economic Community." Asean Economic Community, December 2015. http://asean. org/asean-economic-community/.

Franke, Edith. Einheit in der Vielfalt: Strukturen, Bedingungen und Alltag religiöser Pluralität in Indonesien. Wiesbaden: Harrassowitz, 2012. 
Hefner, Robert W. "Religious Resurgence in Contemporary Asia: Southeast Asian Perspectives on Capitalism, the State and the New Piety." The Journal of Asian Studies: Review of Eastern and Southern Asia and the Adjacent Pacific Islands 69, No. 4 (2010).

Makhmudah, Khoirika. "MEA Dan Semangat Nasionalisme." Koran Muria, December 5, 2015. http:/ /www.koranmuria. com/2015/12/05/24126/mea-dan-semangatnasionalisme.html.

Makin, Al. Antara Barat dan Timur: Batasan, Dominasi, Relasi, dan Globalisasi: Melampaui Jurang Masa Lalu untuk Meniti Jembatan Penghubung. Jakarta: Serambi, 2015.

- "Are There any Indonesian Philosohers? Dealing with a Common Question and Possible Answers." Ulumuna 20, no. 1 (2016).

. "Benedict XVI and Islam: Indonesian Public Reactions to the Regensburg Address." Islam and Christian-Muslim Relations 20, No. 4 (2009).

- Challenging Islamic Orthodoxy, Accounts of Lia Eden and Other Prophets in Indonesia. Dordrecht, Holland; Cinnaminson [N.J.], U.S.A.: Springer, 2016.

- Keragaman dan Perbedaan, Budaya dan Agama dalam Lintas Sejarah Manusia. Yogyakarta: Suka Press, 2016.

. "Revisiting Indonesian Public Reactions against Danish Cartoons Depicting Prophet Muhammad." Indonesian Journal of Islam and Muslim Societies 5, No. 2 (2015).

Nawawi, Iswadi. "Nasib Bahasa Indonesia dalam Telikungan MEA.” Koran Yogya, January 6, 2016. http:/ / koranyogya.

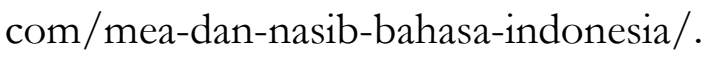

Saparie, Gunoto. "Ketaksiapan Pertanian Hadapi MEA." Koran Muria, June 20, 2015. http://www.koranmuria. com/2015/06/20/5591/ketaksiapan-pertanian-hadapimea.html. 
Al Makin

Tamam, Badrut. "Rupiah dan Daya Saing Indonesia di Pasar MEA.” Jawa Pos, July 4, 2015. http://www2.jawapos. $\mathrm{com} / \mathrm{baca} /$ opinidetail/15381/rupiah-dan-daya-saingindonesia-di-pasar-mea.

Triono, Dwi Condro. "MEA dalam Pandangan Islam.” HisbutTahrir.co.id, January 1, 2016. http://hizbut-tahrir. or.id/2016/01/01/mea-dalam-pandangan- islam/.

Zahra, Nabilah Syifauz. "Efek dan Dampak Pemberlakuan Masyarakat Ekonomi ASEAN (MEA)." Dakwatuna, January 1, 2015. http://www.dakwatuna. com/2015/01/15/62615/efek-dan-dampakpemberlakuan-masyarakat-ekonomi-aseanmea/\#ixzz4GJWQBpKY. 